\title{
Technology dissemination and extension services activated by department of fisheries in south west region of Bangladesh
}

\author{
B. M. S. Rahman, M. A. Samad, M. Khanom and M. Raseduzzaman \\ Fisheries and Marine Resource Technology Discipline, Khulna University, Khulna 9208, Bangladesh
}

\begin{abstract}
The study was conducted in Khulna, Satkhira and Jhenaidah districts under Khulna division. The purpose was to know the training of fishery officers, fish and shrimp farmers in aqua farming. The main dissemination processes are training of farmers, farm demonstration, farmer to farmer visits, leaflets and pamphlets, audiovisuals etc. In Khulna district dissemination and extension services are application of government rules and regulations, strategic management, pond/shrimp farm visit, public awareness, training facilities, financial and other supports and some research projects also applied, training program, the number of trained fish farmers and trained shrimp farmers in 2009 were 790 and 5,754 respectively. In Satkhira district, different extension programs are applied, such as shrimp demonstration, fish sanctuary, pond/shrimp farm visit, training program, the number of trained Fish farmers and trained shrimp farmers in 2009 were 934 and 2110 respectively and community based fisheries management and some research projects. In Jhenaidah district DoF activities are training, in sadar upazila number of trained fisherman 34, baor management, identify floodplain and other involved communities, awareness campaign, frame survey, arrangement of fund, credit facilities, training program, production monitoring, identification of disadvantaged groups and pollution, disease diagnostic and its control.
\end{abstract}

Keywords: Training farmers, Extension, Visits, Demonstration

\section{Introduction}

The term "extension" was first coined in England, not in USA as is often thought (Maunder, 1978). Extension describes all organized communication efforts by which an agency or individual tries to bring about changes in the knowledge, attitudes, skills and behavior of a client population.

This study was conducted to know the extension and dissemination services of modern technology and information on aquaculture and fish conservation as well as to observe the support services supplied by Department of Fisheries (DoF).

Fisheries Extension may be defined as the dissemination of the educational advances of institution to persons unable to take advantage of such in a normal manner. Fisheries extension brings to the fishermen, fish farmers, and fish processors that form of educational assistance best suited to their needs (Kelsey and Hearne 1949).

Department of Fisheries (DoF), Bangladesh was first established in the undivided Bengal of the British India in 1908. DoF aimed to deliver information and new technologies to farmers in order to raise fisheries production. The roles of the Department of Fisheries within such collaborations will normally be coordinating training plans; quality control, monitoring and evaluation. Department of Fisheries disseminates improved aquaculture technologies through training, demonstrating and extending farmers advisory services to the focal stakeholders. Skilled manpower is a prerequisite for fisheries management and aquaculture development. Training is an important tool of extension and is defined as the process of teaching, informing or educating to improve the knowledge, skills and changing the attitude of an incumbent for doing a specific job properly. Training of fish farmers helps to making skilled manpower. Aquaculture training service provides necessary information, skills and knowledge to farmers, fisherman, traders, professional staffs and other agencies in areas of aquatic resource management. A well designed information system is an important requirement in effective extension work (Leagans, 1963). Extension worker in aquaculture must be able to obtain the necessary technical information to improve his/her technical knowledge with the latest research achievements (NAEP, 1996). Extension paves the way for further progress by making the community aware of the benefits to be obtained from the extension program (McAllister, 1981). 


\section{Materials and Methods}

\section{Selection of the study area}

Khulna, Satkhira and Jhenaidah districts under Khulna division were selected for the study. All of these districts are located in south-western region of Bangladesh. Among them Khulna and Satkhira districts were selected as coastal zone and Jhenaidah district as fresh water zone. Fisheries office of three districts and nine upazila under these three districts were surveyed for data collection.

\section{Data collection}

Different data and information both documentary and oral were necessary for the study. Data were mainly collected through office survey. The data were collected in the month of July, 2009 to December, 2009. The data were taken from the following sources:

1) Upazila Fisheries Officer (Fisheries officer, Extension officer, field assistant etc).

2) Districts Fisheries Offices (Khulna, Satkhira \& Jhenaidah districts).

3) Mandate, organogram, extension services, research division, infrastructure facilities, various research projects.

4) Publications and extension booklets made from DoF.

\section{Types of Data collection method}

The study areas were selected on the basis of culture pattern and water quality. Among them Satkhira and Khulna districts are mainly brackish or saline water regions but the Jhenaidah district is only fresh water region. The study area also selected on the basis of cultured species such as in Jhenaidah district no shrimp culture occurred but shrimp is cultured in Satkhira and Khulna districts.

\section{Analysis of data}

The data were collected from District Fisheries Office of Khulna, Satkhira and Jhnaidah. The data were collected from Upazila Fisheries Office of Kalaroa and Tala upazila under Satkhira district as well as from Upazila Fisheries Office of Dighalia, Paikgacha,, Batiaghata, Dumuria and Dakope upazila under Khulna district. The study area also involves Sadar and Kaliganj upazila under Jhenaidah District. The collected data were carefully edited to eliminate errors after sorting and checking. The data were then transferred to tabular forms after careful examination and calculation. The analysis of data was mainly based on tabular and descriptive techniques.

\section{Results and Discussion}

\section{Extension services of Department of Fisheries in south-western part of Bangladesh}

The Department of Fisheries conducted farm visit and having tried to identify problems and provided technical advice to the fishermen. Advisories on farm activities, pond preparation, stocking, fertilizer and manure applications, preparation of composts, pond management, harvesting and marketing, training, publicity and demonstration, input supports and record keeping were supported by the DoF (Thompson et al., 2005).

The Fourth Fisheries Project (FFP) was the largest fisheries project in Bangladesh. It was being implemented by the Department of Fisheries under the Ministry of Fisheries and Livestock. To put it simply, the project aims at increasing fish and shrimp production in Bangladesh, and helping alleviate poverty (Mozammel, 2003). It was launched in 1999-2000, for duration of five years. Pond culture of fish in Bangladesh is spreading far and wide - and fast. The Fourth Fisheries Project is one of the drivers. It aims at training 200,000 farmers from 8,000 villages in 30 districts in culture techniques. $25 \%$ of those already been completed for 90,000 farmers. Another 110,000 have received partial training; they too will complete training in 2004. Twenty five farmers are selected for training from each of 8,000 villages. The training is provided in six sessions over two years. It includes three follow-up sessions in the second year and is backed be extension literature. A farmers' rally is held at the end of the training (FFP, 2005). 
Heelas (1994) reported on Fisheries Extension Services in the Maldives. This report describes the progress, achievements and learning's of a subproject which set out to give directions for the development of a fisheries extension service aimed at the artisanal fisherfolk of the Maldives. The subproject was cleared by the Government of Maldives (GoM) in December 1988 and was initiated in three target atolls - Meemu, Vaavu and Faafu - in April 1989.

Thompson et al., (2005) reported on World Fish project in Kapasia. During 1990-94, ICLARM in collaboration With GOB agencies (DOF, BARC and BFRI) carried out a project named Socioeconomic impact of Fish Culture Extension prograrn on the farming Systems of Bangladesh. 1t was funded by IFAD and DANIDA and was carried out in Gazipur District. It involved both extension and research with many of the households with ponds in a small of this district. Because many ponds were under utilized in terms of fish production, it was expected that an extension program to provide farmers and pond owners with information on pond fish cultivation would have a significant impact on incomes and production. The extension program aimed to make fish cultivation accessible to all rural households; to increase pond fish productivity, on-farm fish consumption and household incomes; and to increase the general supply of fish.

\section{Technology transfer process and extension services in Khulna and Satkhira districts}

The result of this study showed that there were no significant differences in technology transfer process and extension services on fresh and brackish water fish culture between Khulna and Satkhira Districts. Because Khulna and Satkhia districts are in both fresh and brackish water region. DoF applies different government rules and regulations, policy formulation (Strategic Management) and public awareness to promote extensive management and conservation system through mass-media by protecting them from illegal fishing and utilization of existing fisheries resources. Training programme is undertaken for the fish farmers and the entrepreneurs, interested to invest in the fisheries sector. Fish farmers are trained in upazila and union level through the self-program of Department of Fisheries. Many extension activities are provided by DoF, such as fishery demonstration, prawn demonstration, fry release, fish sanctuary, pond and shrimp farm visits etc.

Training program in Khulna district: In Khulna district, many training activities are provided by DoF. Training programmes were undertaken for the fish farmers and the entrepreneurs. Jobless youths were trained for fish culture and financial assistance was provided for their post-training fish culture activities. Arrangements were made to transfer the improved methods of fish culture through regular training in the government fish farms and training centres. The numbers of trained Prawn farmers in 2009 were 5,785. The numbers of trained fish farmers in 2009 were 790 (Table 1).

Table 1. Training program in Khulna district

\begin{tabular}{|c|c|c|c|}
\hline Activities & $\begin{array}{l}\text { In } 2008 \text { achieved } \\
\text { (Number) }\end{array}$ & $\begin{array}{c}\text { In } 2009 \text { Achieved } \\
\text { (Number) }\end{array}$ & $\begin{array}{c}\text { Target in } 2010 \\
\text { (Number) }\end{array}$ \\
\hline \multicolumn{4}{|l|}{ Trained fish farmer } \\
\hline Male & 492 & 525 & 850 \\
\hline Female & 134 & 265 & 434 \\
\hline Male + Female & 626 & 790 & 1,284 \\
\hline \multicolumn{4}{|l|}{ Trained prawn farmer } \\
\hline Male & 2,199 & 5,419 & 6,165 \\
\hline female & 55 & 335 & 970 \\
\hline Male + female & 2,254 & 5,754 & 7,135 \\
\hline Total trained farmer & 2,880 & 6,575 & 8,419 \\
\hline
\end{tabular}

Source: District Fisheries Office, Khulna (2009) 


\section{Research projects conducted in Khulna district in the year of 2005 to 2009}

The following research projects were conducted in Khulna district: Polyculture of shrimps or prawn with commercially important brackish water fin-fishes. improving soil, water, and productivity of gher fishery (Hossain, 2005). Studies on the Impact of Shrimp Farming on Mangrove and Estuarine Environment. Induced Maturation, Artificial Breeding and Culture of Mud Crab (Scyllcr serrata). Studies on the mass seed production of macrobrachium rosenbergii and its nursery and culture system in brackish water environment. Identification, characterization and control of shrimp and prawn diseases (Rahman, 2003).

\section{Running projects in Khulna district}

National Agricultural Technology Projects (NATP) -the responsible authority of NATP organized a training programe to the common interest group with 15 members to make understand about sustainable aquaculture. NATP are being running in Dacope, Batiaghata, Dumuria and Paikgacha upazila. Bagda Culture Technology Extension Project- Training (2 days refresher training and 5 days core training) on bagda culture, Demofarming etc are still being running ranging. Fresh Water Prawn Culture Project is also running in Khulna district. Flood Control Drainage \& Irrigaton (FCDI) projects -along with the help of inland water development board is implementing drainage and irrigation system for controlling flood during rainy season. Demofarming project is being running in Rupsha, Dumuria and Batighata upazila.

Training program in Satkhira district: In Satkhira district many training activities were provided by DoF. The numbers of trained Shrimp farmers in 2009 were 2,110. The numbers of trained fish farmers in 2009 were 934 (Table 2).

Table 2. Training program in Satkhira district

\begin{tabular}{|c|c|c|c|}
\hline Activities & $\begin{array}{c}\text { In } 2008 \text { achieved } \\
\text { (Number) }\end{array}$ & $\begin{array}{c}\text { In } 2009 \\
\text { Achieved } \\
\text { (Number) }\end{array}$ & $\begin{array}{c}\text { in } 2010 \\
\text { Destination } \\
\text { (Number) }\end{array}$ \\
\hline \multicolumn{4}{|c|}{ Trained Fish farmer } \\
\hline Male & 286 & 810 & 1450 \\
\hline Female & 50 & 124 & 519 \\
\hline Male + Female & 336 & 934 & 1969 \\
\hline \multicolumn{4}{|c|}{ Trained shrimp farmer } \\
\hline Male & 2412 & 1789 & 3050 \\
\hline Female & 393 & 321 & 925 \\
\hline Male + female & 2805 & 2110 & 3975 \\
\hline Total & 3141 & 3044 & 5944 \\
\hline
\end{tabular}

Source: District Fisheries Office, Satkhira (2009)

\section{Research projects conducted in Satkhira district in the year of 2005 to 2009}

Development of prevention and control protocols of commonly occurring shrimp diseases in Bangladesh. Development of mass seed production and nursery system of golda (Mcrcrobraclaium rosenhergii) and bagda (Penaeus monodon). Polyculture trials on shrimp and some freshwater and hy posaline fin fish species in brackishwater environment. Development of live food culture for brackishwater fish and shrimp species. Development of artificial diet from locally available ingredient for shrimp.

Extension activities in Jhenaidah district: Department of Fisheries (DoF) involved in the fingerling production and floodplain stocking. Awareness campaign and arrangement of fund were made for raising fingerlings for stocking floodplain. Organized training program for the group members who were involved for raising fingerlings and management of fishers. DoF involved beel management, habitat improvement and activities on pollution, disease diagnosis and control. DoF has distributed 20 thousand leaflets to create awareness among people about the importance of fish conservation in the year of 2007 to 2009. Upazila Fisheries Department announced different rules and regulation of fish conservation act at different location of the Jhenaidah in order to make aware of the people. Bolohor baor at Kotchandpur upazila managed by DoF. The total area of the baor is about $282 \mathrm{ha}$. 


\section{Running projects in Jhenaidah district}

National Agricultural Technology Projects (NATP): There were about 40 and 34 fishermen got training under NATP projects in Kaligonj and sadar upazila respectively. Fourth Fisheries Project (FFP) -The objective of the FFP was the Aquaculture Extension and Training (AET) based on the Participatory Rural Apprisal (PRA). About 1,000 fish farmer got training under FFP in Kaligonj upazila. This project also execute "Fish Culture for Food program" in Kaligonj upazila.

\section{Methods of extension in south-west region}

The fisheries officer at upazila, district, divisional and national levels offer technical advice to the individual office callers. Farm visits-The extension officer visits a specific farm by the request of a fish farmer and have a look of investigation gave advice to the farmer. Training and workshops- Training and workshops are frequently organized at upazila and district levels for the farmers. Training sessions are also organized at the DoF fish seed farms and training centers. Informal meetings- Informal meetings are a common practice in establishing feedback between the farmers and the extension workers. PGTS methods-Pond Side Group Training Session method is applied for training. The extension officer provides training among the fish farmers near the pond or embankment of the pond. They discussed about the culture system and demonstrate the application method for practical session. Participatory Rural Appraisal / Participatory Learning and Action (PRA/ PLA) methods used for training of the farmers. (Huda, 1999).

\section{Production in South-West Region through implementation of extension program by DoF}

The South-West Region of Bangladesh is very rich in aquaculture. Every year a lot of foreign currency earn by export of fish \& fisheries products. The aquaculture production in South-West Region varies from area to area. In Satkhira district, aquaculture production is high than other area. Bangladesh has extensive areas of fresh water, brackish water and marine water. The potential for development of these resources is immense. The Khulna region has numerous rivers, beels, boars, canals, lakes, in undated lands and creeks. The brackish water area of the region is predominant. All the water bodies of this region are potentially enriched with a wide diversity of physical and biological resources. The extension techniques are of the same general pattern as discussed under Individual and Group extension approaches, the use of mass media, training and visits at demonstration farms are the usual extension techniques. Under certain projects, contract farmers are provided with interest-free loans for selected production inputs in order to expedite adoption of new technology.

Annual Production of Shrimp/Prawn and fish in Khulna districts is $33,437.13 \mathrm{mt}$, Satkhira district is $27,801.51 \mathrm{mt}$ and Jhenaidah district is 2.30 . The lowest production in Jhenaidah district (Fig. 1).

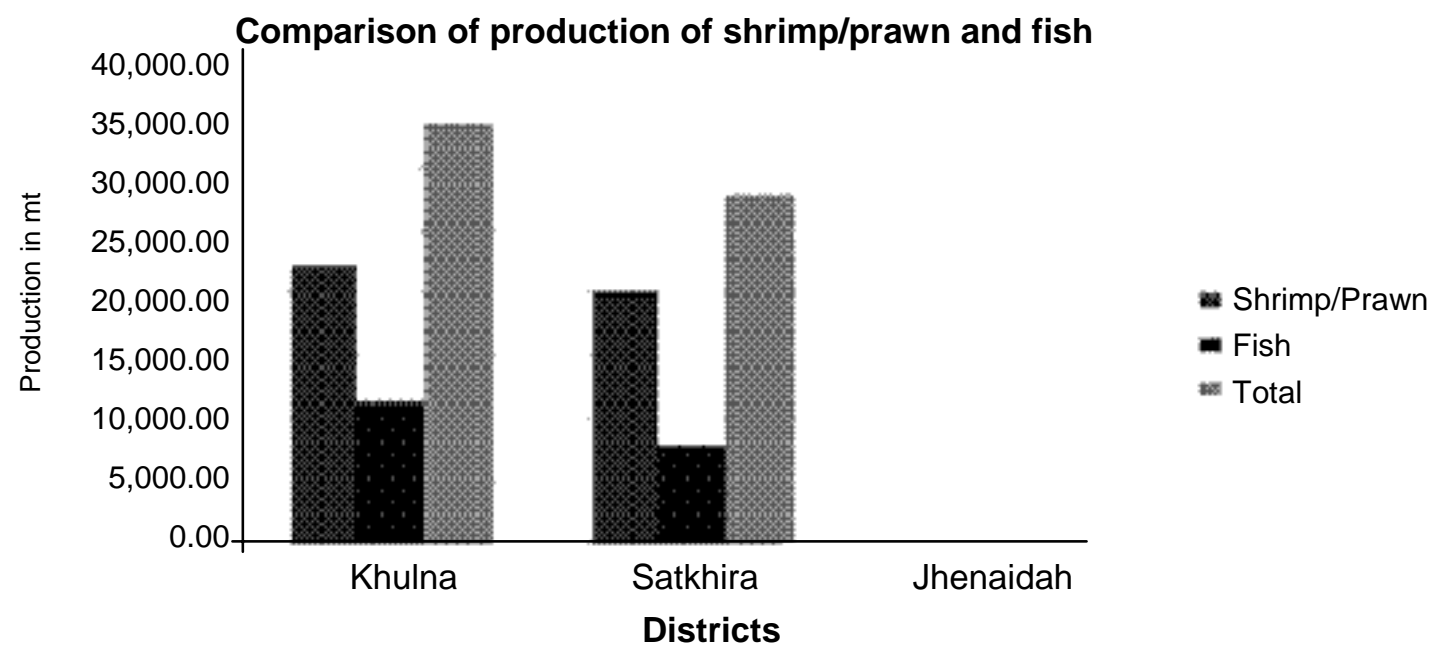

Fig. 1. Prawn/Shrimp and fish Farm Production 


\section{Conclusion}

Aquaculture is a high priority development sector, especially in south-west region of Bangladesh. Because of continuous deterioration of open water fisheries due to natural and anthropogenic changes in the fish habitats and fish populations, this sector prone to a serious crisis. The Government has endeavored to increase fish production through aquaculture. DoF identified the commonly occurring shrimps and prawn disease in Bangladesh. Department of Fisheries transferred the research findings to the target group of people. DoF identified the causes of biodiversity losses of the Sundarban regions of the country. Department of Fisheries provides small scale loan to the farmers. DoF make groups by 5 to 7 fish farmers and provides loan among them. On the basis of the findings of the study it can be suggested that Extension worker should identify the problems that concern the people in his region and he should see to it that local leaders are involved in setting the objectives and setting-up plans for the extension activities in the community. The amount of loan is not sufficient for achievement of handsome aquaculture production, so it should be increased. Government should urgently establish essential infrastructure facilities, e.g., roads and waterways and telephone connections in the local areas.

\section{References}

FFP (Fourth Fisheries Project). 2005. What it is, What it Does. Eknajore Prokasona Karjokrom, DoF, Matshaya Adhidaptar, Bangladesh. pp. 40-46.

Heelas, A.M.H. 1994. Bay of Bengal Program on Fisheries Extension Services in the Maldives.

Hossain, A.K.I. 2005. Impact of Training on Shrimp And Prawn Farmers of Paikgacha And Dumuria Region In Khulna B. Sc. thesis, Fisheries and Marine Resource Technology Discipline, Khulna University, Khulna., 8, 10-28.

Huda, E. 1999. Unnayane Jonogoner Oangsagrahan (peoples participation in Bangladesh). A manual on PRA/PLA for trainers, practitioners and promoters. pp. 43-44.

Kelsey, L.D. and Hearne, C.C. 1949.Cooperative Extension Work, Constock, Itchaca, New York. 29 pp.

Leagans, J.P. 1963. Guides to extension teaching in developing countries, Cornell University, Itchaca, New York. pp. 7-8.

Maunder, A.H. 1978. Agricultural Extension: A reference manual, FAO, Rome, 3rd printing. 1pp.

McAllister, J. 1981. Rural innovators: a struggle for power. In: Extension Education and Rural Development. Vol. 1. Ed. B. R. Crouch and S. Chamala. John Wiley \& Sons. Chichester, New York, Brisbane, Toronto. pp. 135-145.

Mozammel, H. Md. 2003. Study on the Impact of Fisheries Extension and Training Program in Fishery Village of Fourth Fisheries Project in Tarash Upazilla, Serajgonj. M. Sc. Thesis submitted to Fisheries and Marine Resources Technology, Khulna University.

NAEP (New Agricultural Extension Policy). 1996. Government of the People's Republic of Bangladesh, Ministry of Agriculture. pp. 5-10.

Rahman, M.S. 2003. Role of Brackishwater Station, Paikgacha in Fisheries Development. B. Sc. thesis, Fisheries and Marine Resource Technology Discipline, Khulna University, Khulna.

Thompson, P.M., Sultana, P. and Khan, A.K.M. 2005. Aquaculture extension impacts in Bangladesh : A case study from Kapasia, Gazipur. World fish centre technical reports. pp. 1-5. 